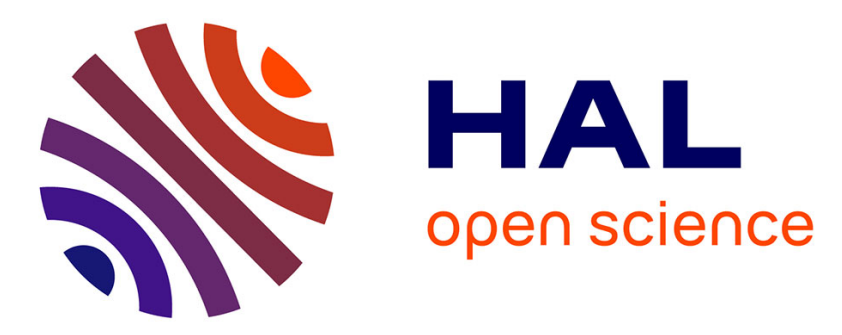

\title{
Study of water behaviour of chemically treated flax fibres based composites: a way to approach the hydric interface
}

\author{
S. Alix, L. Lebrun, C. Morvan, S. Marais
}

\section{> To cite this version:}

S. Alix, L. Lebrun, C. Morvan, S. Marais. Study of water behaviour of chemically treated flax fibres based composites: a way to approach the hydric interface. Composites Science and Technology, 2011, 71 (6), pp.893. 10.1016/j.compscitech.2011.02.004 . hal-00736293

\section{HAL Id: hal-00736293 \\ https://hal.science/hal-00736293}

Submitted on 28 Sep 2012

HAL is a multi-disciplinary open access archive for the deposit and dissemination of scientific research documents, whether they are published or not. The documents may come from teaching and research institutions in France or abroad, or from public or private research centers.
L'archive ouverte pluridisciplinaire HAL, est destinée au dépôt et à la diffusion de documents scientifiques de niveau recherche, publiés ou non, émanant des établissements d'enseignement et de recherche français ou étrangers, des laboratoires publics ou privés. 


\section{Accepted Manuscript}

Study of water behaviour of chemically treated flax fibres based composites: a way to approach the hydric interface

S. Alix, L. Lebrun, C. Morvan, S. Marais

PII:

S0266-3538(11)00071-6

DOI:

10.1016/j.compscitech.2011.02.004

Reference:

CSTE 4929

To appear in:

Composites Science and Technology

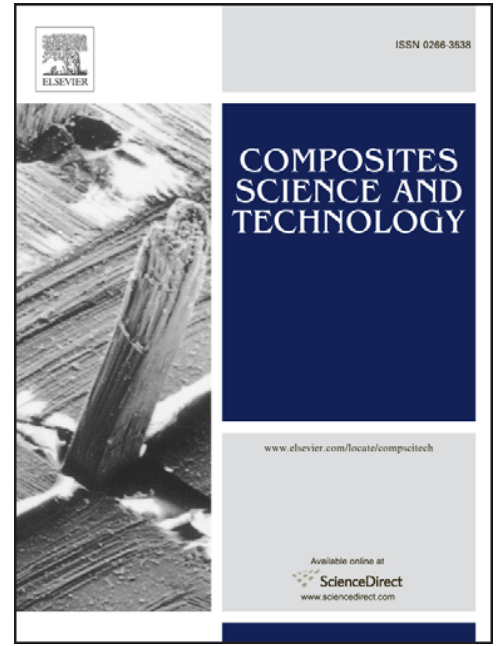

Received Date: $\quad 9$ September 2010

Revised Date: $\quad 9$ February 2011

Accepted Date: $\quad 13$ February 2011

Please cite this article as: Alix, S., Lebrun, L., Morvan, C., Marais, S., Study of water behaviour of chemically treated flax fibres based composites: a way to approach the hydric interface, Composites Science and Technology (2011), doi: 10.1016/j.compscitech.2011.02.004

This is a PDF file of an unedited manuscript that has been accepted for publication. As a service to our customers we are providing this early version of the manuscript. The manuscript will undergo copyediting, typesetting, and review of the resulting proof before it is published in its final form. Please note that during the production process errors may be discovered which could affect the content, and all legal disclaimers that apply to the journal pertain. 


\title{
Study of water behaviour of chemically treated flax fibres
}

\section{based composites: a way to approach the hydric interface}

\author{
S. Alix, L. Lebrun, C. Morvan, S. Marais ${ }^{*}$ \\ Laboratoire "Polymères, Biopolymères, Surfaces", UMR 6270 and FR3038 INC3M, \\ Université de Rouen/CNRS, UFR des Sciences, 76821 Mont-Saint-Aignan Cedex, \\ France
}

\section{Abstract}

Silane ( $\mathrm{Si}$ ) and styrene $(\mathrm{S})$ treatments were applied on flax fibres in order to improve their adhesion with a polyester resin and to increase their moisture resistance. The water sorption and permeation kinetics of the composites were correlated with the water sorption behaviour of untreated and treated fibres. An increase of the water barrier effect was observed in treated fibres-based composites in comparison with untreated ones. This was related to the shift-down of water solubility and to a decrease of the water diffusivity in treated fibre-based composites. In the case of (S) treatment, the presence of styrene increased the moisture resistance of the treated fibres and made compatible the fibres and the matrix. In the case of ( $\mathrm{Si})$ treatment, a good hydric fibre/matrix interface was obtained due to crosslinking reactions and hydrogen bonding between water molecules and free hydroxyl groups of $(\mathrm{Si})$ treated fibres. In order to interpret water permeation behaviour of composite films, a simple illustrated model is suggested and represented by a schematic view.

Keywords: A. Fibres; A. Polymer-matrix composites (PMCs); B. Interface ; B. Transport properties; C. Permeability.

\footnotetext{
* Corresponding autor. Tel +33- 235146702

E-mail address: stephane.marais@univ-rouen.fr
} 


\section{Introduction}

Cellulosic fibres originating from plant stem are mainly composed by polysaccharides and consequently are highly hydrophilic. The great moisture sorption of natural fibres adversely affected adhesion with hydrophobic matrix leading to premature ageing by degradation and loss of strength $[\mathbf{1 , 2 , 3}$. Understanding the water diffusion mechanisms in these materials is essential for the improvement of the adhesion quality. Moreover, water absorption in the fibre/matrix interface has been identified as one of the main long-term effects leading to the reduction of mechanical properties through interfacial cracking in polymer matrix of composite materials [4]. To prevent this phenomenon, fibres should be chemically modified in order to increase the moisture resistance and to improve matrix/fibre adhesion. In literature, several authors had reported on chemical modifications of cellulose [5]. Different chemical molecules had been grafted on fibres such as stearic acid [6,7], maleic anhydride [8,9], sodium hydroxide [10,11,12], acetic acid/anhydride $[\mathbf{1 0 , 1 1 , 1 2}]$, isocyanates $[\mathbf{1 3}, \mathbf{1 4}]$ and silanes $[\mathbf{1 5}, \mathbf{1 6}, \mathbf{1 7}]$. Kinetics of water sorption in phenol-formaldehyde based-composites reinforced with oil palm fibres, glass fibres and oil palm/glass hybrid fibres were investigated by Sreekala et al. [18]. They analysed the behaviour of composites after modification on the fibre surface by sodium hydroxide solution, peroxide, silane, isocyanate, or permanganate... They showed that void formation induced the decrease of the fibre/matrix interactions and thus enhanced water sorption of composites.

In the course of our studies on water-barrier properties of polymeric films $[\mathbf{1 9 , 2 0}]$, as well as on water-sorption properties of natural fibres [21,22], we focused on interface behaviour of composites $[\mathbf{2 3 , 2 4}]$. The aim of this study was to investigate the hydric interface in unsaturated polyester matrix reinforced with flax fibres. Two different 
treatments were applied on fibres: 1) styrene treatment (S) [21] and 2) silane treatment (Si) [25]. To analyse how flax fibre behaviour towards water molecules might impact the properties of composites, water sorption and permeation measurements were performed on composites and analysed by taking into account the water vapour sorption results obtained from treated fibres [22].

\section{Material and Methods}

\subsection{Flax fibres}

Flax fibres (Hermes variety of the year 2004) were provided by Dehondt Technology Company (Notre-Dame de Gravenchon, France). As previously described [22], they originated from the middle part of the retted stems and were provided as scutched technical fibres. They consisted mainly of elementary fibres gathered into small group whose average diameter had been estimated to $85 \pm 20 \mu \mathrm{m}(\mathrm{n}=2000)$. This average diameter has been determined by optical microscopy for 100 technical fibres whose mean diameter was calculated from 20 measures taken along the length.

\subsection{Organic matrix}

Unsaturated polyester resin (UPR) Norsodyne G 703 was provided by Cray Valley (Gravigny, France). UPR consisted of anhydrid maleic $(15 \% \mathrm{~mol} / \mathrm{mol})$, isophthalic acid $(15 \% \mathrm{~mol} / \mathrm{mol})$, propylene glycol $(30 \% \mathrm{~mol} / \mathrm{mol})$ and styrene $(40 \% \mathrm{~mol} / \mathrm{mol})$ as grafting agent.

\subsection{Chemical treatments of flax fibres}


Before the treatment, the technical fibres $(2 \mathrm{~g})$ were dried overnight in a convection oven at $60^{\circ} \mathrm{C}$. After each treatment, the fibres were dried and stored at room temperature.

\subsubsection{Styrene $(S)$}

The fibres were treated in a $50 \mathrm{~cm}^{3}$ solvent mixture of toluene/styrene (Aldrich, 99\%) 45/5 v/v and $0.12 \mathrm{mg}$ benzoyl peroxide (Fluka, $97 \%$ ) for $3 \mathrm{~h}$ at room temperature and for $3 \mathrm{~h}$ at $80^{\circ} \mathrm{C}$. No washing was performed after the treatment in order to optimise the compatibility between the fibres and the matrix (styrene, being the solvent of the matrix).

\subsubsection{Silane (Si)}

The treatment of fibres with $\gamma$-methacryloxypropyltrimethoxysilane ( $\mathrm{Si}$ ) (Acros, $98 \%$ ) $(0.05 \mathrm{M})$ was carried out in $80 / 20 \mathrm{v} / \mathrm{v}$ ethanol/water $\left(40 \mathrm{~cm}^{3}\right)$ for $24 \mathrm{~h}$ under nitrogen atmosphere and heated at $100^{\circ} \mathrm{C}$ for $4 \mathrm{~h}$ in order to promote the chemical coupling. After the treatment, fibres were washed in an ethanol/water $(80 / 20 \mathrm{v} / \mathrm{v})$ solution at room temperature.

\subsection{Preparation of the composites}

The UPR was hardened via a radical process. The cobalt octoate accelerator solution $(0.2 \% \mathrm{w} / \mathrm{w})$ was first mixed with the resin $(2 \mathrm{~min})$ and the solution was out gazed under vacuum $(5 \mathrm{~min})$. Then, the methylethylketone peroxide initiator solution $(1.5 \% \mathrm{wt}$. was added to the mixture ( $2 \mathrm{~min})$. The composite materials were prepared by pouring the UPR (in liquid state) onto one layer of technical fibres ( $45 \%$ wt.) undirectionally 
strectched in a steel built mould (Figure 1). The composite (in the mould) was placed under press (15 MPa) at ambient temperature for $24 \mathrm{~h}$ in order to obtain a calibrated thickness $(400 \pm 60 \mu \mathrm{m})$. This thickness value was chosen as the maximum to run permeation experiment in a reasonable time. Then, the composite was post-cured at 80 ${ }^{\circ} \mathrm{C}$ (for $6 \mathrm{~h}$ ) and at $130{ }^{\circ} \mathrm{C}$ (for $2 \mathrm{~h}$ ) to ensure a maximum conversion of styrene and to have an optimal resin reticulation [26]. The micrograph in Figure 2 showed a typical geometry of the composites with a relatively even distribution of the fibres within the matrix width. On the other hand, the one layer of technical fibres remained rather localised in the middle of the matrix depth and completely embedded in the matrix (4 over 5 cases, as seen by scanning electronic microscopy, data not shown).

\subsection{Liquid water sorption measurements}

Liquid water sorption tests were carried out on the UPR matrix and composite films. All the specimens $\left(30 \times 25 \times 0.5 \mathrm{~mm}^{3}\right)$ were dried before testing in desiccators containing pentoxide phosphorus. After some days, they were removed and weighted with an accuracy of $\pm 0.0001 \mathrm{~g}$ using an Ohaus Explorer balance. This cycle was repeated until a constant mass $\left(M_{d}\right)$ was obtained. Then, the films were immersed in distilled water at $20^{\circ} \mathrm{C}$. At fixed time intervals they were removed, cautiously dry blotted to remove water excess, weighted and immersed again in water. The uptake of water was recorded until there was no significant change in weight, i.e. equilibrium was reached $\left(M_{w(e q)}\right)$. The experiment took about $50 \mathrm{~h}$ for the resin and $300-400 \mathrm{~h}$ for the composites.

The equilibrium mass gain $M\left(\mathrm{~g}_{\text {water }} / \mathrm{g}_{\text {matter }}\right)$ was defined by the ratio of the difference between wet $M_{w(e q)}$ and dry mass $M_{d}$ to dry matter mass: 


$$
M=\frac{M_{w_{(e q)}}-M_{d}}{M_{d}}
$$

\subsection{Water permeation measurements}

Water permeation tests were carried out on the UPR and composite films using the permeation apparatus previously described [19]. The apparatus consisted of a measurement cell (flushing by dry nitrogen) and a hygrometric unit as the sensor (chilled mirror hygrometer, General Eastern Instruments, MA, USA). The film under test was inserted in the cell (effective area $A=1.68 \mathrm{~cm}^{2}$ ) and dry nitrogen was flushed into both compartments for many hours (at least $20 \mathrm{~h}$ ) until a dew point temperature lower than $65^{\circ} \mathrm{C}$ was obtained. After this dry step, a stream of liquid water was pumped through the upstream compartment. The water concentration in the initially dry sweeping gas was monitored in the downstream compartment via the hygrometer and a data acquisition system. The flux of water vapour $J(L, t)$ (in $\left.\mathrm{mmol} \cdot \mathrm{cm}^{-2} \cdot \mathrm{s}^{-1}\right)$ at $t$ time at the dry interface was obtained from:

$$
J(L, t)=\frac{f}{A} \cdot 10^{-6} \cdot \frac{\left(x^{o u t}-x^{i n}\right)}{R \cdot T} \cdot p_{t}
$$

where $L$ is the film thickness $(\mathrm{cm}), t$ the time $(\mathrm{s}) ; f$ the nitrogen gas flow $\left(\mathrm{cm}^{3} . \mathrm{s}^{-1}\right), p_{t}$ the total pressure usually $1 \mathrm{~atm}, \mathrm{R}$ the ideal gas constant $\left(\mathrm{R}=0.082 \mathrm{~atm} \cdot \mathrm{cm}^{3} \cdot \mathrm{K}^{-1} \cdot \mathrm{mmol}^{-1}\right)$ and $T$ the temperature $(\mathrm{K})$ of the experiment. The water concentration $x$ (in ppmV) was calculated from the water vapour pressure $p$, which was directly related to the sweeping gas dew point temperature $T_{d p}$ at the inlet $\left(x^{\text {in }}\right)$ and the outlet $\left(x^{\text {out }}\right)$ of the cell [23].

All the water permeation tests were carried out at $298 \mathrm{~K}$.

For each material tested, the steady state was reached and was quantified by a value $J_{s t} . L$. From the knowledge of the stationary flux $J_{s t}$, the values of the permeability 
coefficient $P$ (usually expressed in Barrer $=10^{-10} \mathrm{~cm}^{3}(\mathrm{STP}) \cdot \mathrm{cm} \cdot \mathrm{cm}^{-2} \cdot \mathrm{s}^{-1} \cdot \mathrm{cmHg}^{-1}$ ), were determined according to

$$
P=\frac{J_{s t} \cdot L}{\Delta a_{W}}
$$

where $L$ is the thickness of the composite film and $\Delta a_{w}$ the difference in activities between the two faces of the film. Bearing in mind that composite films were not homogeneous materials, the calculated permeability coefficient represented a mean value of the permeability.

Using reduced flux $(J \cdot L)$ with the reduced time $t / L^{2}$, the data can be analysed independently of the material thickness, $L$ [27]. These measurements allow to show the influence of the chemical treatments on the water diffusivity. Because of the heterogeneous structure of the composite material, the Fick's laws cannot be applied to determine a diffusion coefficient. Consequently, the diffusion parameter was approached looking at 3 characteristic values of time delay taken at the beginning, middle and end of the transient regime curve, defined as: 1) the drilling time, $t_{d}$, (calculated for $J=0.01 \cdot J_{s t}$ ), 2) the time-lag, $t_{L}$, (for $J=0.617 \cdot J_{s t}$ ) and 3 ) the establishment time, $t_{e}$, (for $\left.J=0.99 \cdot J_{s t}\right)[28]$.

It should be mentioned that the permeability not depends only on the diffusivity, the kinetic parameter, but also on the solubility, the thermodynamic parameter. The solubility coefficient $S$ (expressed in $\left.\mathrm{cm}^{3}(\mathrm{STP}) \cdot \mathrm{cm}^{-3} \cdot(\mathrm{cmHg})^{-1}\right)$ is given by the following relation [29]:

$$
S=\frac{C}{a_{W}}
$$


where $C$ is the concentration in the composite and $a_{w}$ the water activity in the environment of the sample.

\section{Results and discussion}

\subsection{Liquid water sorption in matrix and in composites}

As shown in Figure 3a, the mass gain of the UPR matrix was around $1 \%$ of water. After $300 \mathrm{~h}$, the water sorption of composites reinforced with $40 \%$ (wt/wt) of untreated flax fibres was increased to $\simeq 6 \%$. When the composites were composed of treated fibres (for similar amount of fibres), the water sorption was found in the range of 5-6\% meaning that the moisture resistance was enhanced. Similar measurements on composites composed of an unsaturated polyester matrix reinforced by hemp fibres showed that the mass gains were 3 to $11 \%$ for fibre contents of 10 to $26 \%$ (wt/wt) and that the moisture uptake increased with the fibre volume fraction due to increased voids and hydrophilic polysaccharide content [30].

In a previous paper [22], from the equilibrium state of water vapour kinetics, sorption isotherms were deduced for untreated, $(\mathrm{S})$ treated and $(\mathrm{Si})$ treated flax fibres. From this study, it was interesting to check at which water vapour activity the isolated fibres absorbed the same water amount as the one measured in the composite. These mass gains were calculated on the basis of the mixture law and from data of Figure 3a and reported on the water vapour sorption isotherm curves (inserts). Doing so, the water activities extrapolated at the interfaces between matrix and fibres were estimated to be 0.45, 0.46 and 0.27 when using untreated, $(\mathrm{S})$ treated and $(\mathrm{Si})$ treated fibres, respectively. These results pointed out the particular liquid water sorption behaviour of composites reinforced with (Si) treated fibres. In other words, it all seems as if the water 
solubility was lower in composites reinforced with $(\mathrm{Si})$ treated fibres compared to untreated and (S) treated ones. Nevertheless, the comparison of the isotherms obtained with isolated fibres did not suggest such an affect: (Si) fibre curve was very close to that of the untreated fibres [22]. Alternatively, such effect could be interpreted by the role of the fibre/matrix interface. The interface might be less hydrophilic due to covalent linkages between on the one hand the fibre and silane and on the other hand between the unsaturated group of silane and the matrix. This resulted into a decrease of the volume of the interface and-hydrogen bounds might be formed between water and silane hydroxyl groups.

In Figure 3b, the variation of the water mass uptake of the composites $\Delta M / \Delta M_{e q}$ was represented versus the reduced time $t / L^{2}$ in order to neglect the influence of the film thickness. This representation allowed highlighting the water diffusivity phenomena in the composite. The presence of fibres reduced the water diffusivity. In the case of untreated fibres, the increase of the delay time could be attributed to the presence of fibres acting as a tank, able to retain water molecules. "Water tank" effects could correspond to the trapping of water molecules into micro and macrovoids of the bundle fibres (space between fibres) and inside the single fibres (lumen). The delay effect was more marked when the fibres were chemically treated, with styrene especially. This result is consistent with the limited sorption obtained with (S) treated fibres [22]. In the case of $(\mathrm{Si})$ treated fibres, this phenomenon was due to the improvement of the interface fibre/matrix quality. To confirm these preliminary results, water permeation measurements were performed. 


\subsection{Water permeation through matrix and composites}

The introduction of flax fibres in the UPR matrix increased the water permeability coefficient due to their hydrophilic nature (increase of the water solubility) (Table 1).

As shown in Figure 4a, both treatments, $(\mathrm{S})$ and $(\mathrm{Si})$ lead to reduce the permeability of flax fibre reinforced composites, especially as the treated fibre contents in composites are higher than untreated fibres. From liquid water sorption results of composites, it is clear that the reduction of water solubility allows the reduction of the permeability. In terms of water barrier effect, $(\mathrm{S})$ treatment was more efficient with a reduction of $P$ of $75 \%$ than (Si) treatment (68\%) (Table 1). Water barrier-effects had been also observed in unsaturated polyester based on flax fibres after autoclave and/or plasma treatments but they were less efficient in comparison with ours [23].

For the water diffusivity, good indicators were the drilling times, $t_{d}$, the establishment time, $t_{e}$, and the time-lag $t_{L}$ and were given in Table 1. The characteristic times $t_{d}, t_{L}$, and $t_{e}$ obtained with fibre-reinforced composite materials increased compared to the UPR results, in particular, when the fibres were chemically treated (see Figure $\mathbf{4 b}$ ). These significant decreases in water diffusivity consisted of an additional factor to the reduction of $P$, together with the water solubility $S$. Similar tendencies, in terms of water diffusivity and permeability, were obtained with UPR/flax fibre-based composites before and after plasma treatment [23].

In order to interpret water permeation behaviour of composite films, a simple illustrated model was suggested and represented by the schematic view of Figure 5. From this model, the composite material is composed of three domains: matrix, fibres and fibre/matrix interface. In terms of water transport, each domain is characterised by a 
diffusion coefficient $D$ and solubility coefficient $S$ (called $D_{m}, S_{m}$ for the matrix, $D_{f}, S_{f}$ for the fibres and $D_{i}, S_{i}$ for the fibre/matrix interface).

In the case of untreated flax fibre-based composite, the water solubility was found higher in the fibre than in the matrix. The water solubility in this interface was closer to the one in fibres than the one in the hydrophobic matrix and could partly explain the high increase of $P$. The difference of chemical nature between matrix (hydrophobic) and untreated fibres (hydrophilic) induced a weak matrix/fibres interface which can favour a percolation phenomenon.

About composites reinforced by $(S)$ treated fibres, $D_{f}$ and $S_{f}$ were reduced by the treatment as reported previously [22]. This behaviour was optimized due to the reduction of water activity at the interface leading to the reduction of $D_{i}$ and $S_{i}$ compared to ones of untreated flax fibres based composites. The increase of water barrier effect due to $(\mathrm{S})$ treatment could be interpreted as an improvement of the fibre/matrix interface quality resulting of a better compatibility with styrenic groups, in the hydrophobic matrix (styrene being the grafting agent of the resin) and in the fibres (treatment). Consequently, the percolation phenomenon was reduced increasing the diffusion pathway of water molecules through the composite and so reduced the permeability (stationary permeation flow). Similar results had been obtained with UPR/alfa fibre-based composites [24]. The increase of moisture resistance of (S) treated fibres (reduction of water sorption) and the improvement of the fibre/matrix interface participated to the reduction of the permeability.

In a previous paper [22], kinetic results of water sorption performed on fibres showed that the $(\mathrm{Si})$ treatment did not change their water vapour behaviour. However, for $(\mathrm{Si})$ treated fibres based composites, reductions of water permeability and diffusivity were 
observed, in accordance with liquid water sorption measurements carried out with composites. The $(\mathrm{Si})$ treatment impact on water sorption and water permeation of composites could be interpreted only by an interface effect. The matrix/fibre interface might be improved by crosslinking reactions between unsaturations of grafting silane groups and matrix ones (unsaturated polyester chains). Moreover, a hydric interface could be generated due to the formation of hydrogen bonds between water molecules and the free hydroxyl groups on silane [25], reducing the water mobility. These two concomitant effects could explain why the delay time was more increased with $(\mathrm{Si})$ treated fibres-based composites than with $(\mathrm{S})$ treated fibre ones.

\section{Conclusions}

The results of the present study showed that the use of $(\mathrm{S})$ and $(\mathrm{Si})$ treatments of the flax fibres enhanced the water resistance and the permeametric properties of composite films. Moreover, our data evidenced a difference in the mechanism of hydric interface building. Interestingly, the properties of $(\mathrm{Si})$ treated fibre-based composites where specifically acquired during the composite elaboration. On the other hand, the properties of (S) treated fibre-based composites mainly depended on the modified fibre behaviour.

To better understand the influence of chemical treatments on the hydric interfaces, the topography of fibre surface and interface transverse section (SEM, AFM microscopies...) might be investigated. The hydric interface is linked to the fibre/matrix adhesion and hence depends not only on the chemical nature of the different components but also on the roughness/smoothness of fibre surface.

Also, the relationship between hydric and mechanical interfaces might be investigated. Indeed, we have previously shown that $(\mathrm{Si})$ treatment improved the mechanical 
properties of the fibres while $(\mathrm{S})$ treatment might have a negative impact [22]. The quality of the interface could be examined by other mechanical methods as fragmentation [31], nanoindentation [32,33] and pull-out tests [34].

\section{References}

[1] Camino G, Luda MP, Polishchuck A, Revellino M, Blancon R, Merle G, Martinez-Vega JJ. Kinetic aspects of water sorption in polyester-resin/glass-fibre composites. Compos Sci Technol 1997;57:14691482.

[2] Morii T, Ikuta N, Kiyosumi K, Hamada H. Weight-change analysis of the interphase in hygrothermally aged FRP: consideration of debonding. Compos Sci Technol 1997;57:985-990.

[3] de Albuquerque AC, Kuruvilla J, de Carvalho LH, Morais d'Almeida JR. Effect of wettability and ageing conditions on the physical and mechanical properties of uniaxially oriented jute-roving-reinforced polyester composites. Compos Sci Technol 2000;60:833-844.

[4] Bao LR, Yee AF. Moisture diffusion and hygrothermal aging in bismaleimide matrix carbon fiber composites_-part I: uni-weave composites. Compos Sci Technol 2002;62:2099-2110.

[5] Bledzki AK, Gassan J. Composites reinforced with cellulose based fibres. Prog Polym Sci $1999 ; 24: 221-274$

[6] Lodha P, Netravali AN. Characterization of stearic acid modified soy protein isolate resin and ramie fiber reinforced "green” composites. Compos Sci Technol 2005;65:1211-1225.

[7] Torres FG, Cubillas ML. Study of the interfacial properties of natural fibre reinforced polyethylene. Polym Test 2005;24:694-698.

[8] Cantero G, Arbelaiz A, Llano-Ponte R, Mondragon I. Effects of fibre treatment on wettability and mechanical behavior of flax/polypropylene composites. Compos Sci Technol 2003;63:1247-1254.

[9] Pickering KL, Beckermann GW, Alam SN, Foreman NJ. Optimising industrial hemp fibre for composites. Compos Part A-Appl S 2007;38:461-468.

[10] Van de Weyenberg I, Chi Truong T, Vangrimde B, Verpoest I. Improving the properties of UD flax fibre reinforced composites by applying an alkaline fibre treatment. Compos Part A-Appl S 2006;37:1368-1376.

[11] Jähn A, Schröder MW, Füting M, Schenzel K, Diepenbrock W. Characterization of alkali-treated flax fibres by means of FT Raman spectroscopy and environmental scanning electron microscopy. Spectrochim Acta, Part A 2002;58:2271-2279.

[12] Qin C, Soykeabkaew N, Xiuyuan N, Peijs T. The effect of fibre volume fraction and mercerization on the properties of all-cellulose composites. Carbohyd Polym 2008;71:458-467.

[13] Karmarkar A, Chauhan SS, Modak JM, Chanda M. Mechanical properties of wood-fiber reinforced polypropylene composites: Effect of a novel compatibilizer with isocyanate functional group. Compos Part A-Appl S 2007;38:227-233. 
[14] Gironès J, Pimenta MTB, Vilaseca F, De Carvalho AJF, Mutjé P, Curvelo AAS. Blocked isocyanates as coupling agents for cellulose-based composites. Carbohyd Polym 2007;68:537-543.

[15] Ismail H, Shuhelmy S, Edyham MR. The effects of a silane coupling agent on curing characteristics and mechanical properties of bamboo fibre filled natural rubber composites. Eur Polym J 2002;38(1):3947.

[16] Pickering KL, Abdalla A, Ji C, McDonald AG, Franich RA. The effect of silane coupling agents on radiata pine fibre for use in thermoplastic matrix composites. Compos Part A-Appl S 2003;34:915-926.

[17] Hong CK, Hwang I, Kim N, Park DH, Hwang BS, Nah C. Mechanical properties of silanized jutepolypropylene composites. J Ind Eng Chem 2008;14:71-76.

[18] Sreekala MS, Kumaran MG, Thomas S. Water sorption in oil palm fiber reinforced phenol formaldehyde composites. Compos Sci Technol 2002;33:763-777.

[19] Marais S, Métayer M. Water diffusion and permeability in unsaturated polyester resin films characterized by measurements performed with a water specific permeameter. Analysis of transient permeation. J Appl Polym Sci 1999;74:3380-3395.

[20] Marais S, Métayer M, Labbé M, Valleton JM, Alexandre S, Saiter JM, Poncin-Epaillard F. Surface modification by low-pressure glow discharge plasma of an unsaturated polyester resin: effect on water diffusivity and permeability. Surf Coat Tech 1999;122:247-259.

[21] Bessadok A, Marais S, Gouanve F, Colasse L, Zimmerlin I, Roudesli S, Metayer M. Effect of chemical treatments of Alfa (Stipa tenacissima) fibres on water-sorption properties. Compos Sci Technol 2007;67:685-697.

[22] Alix S, Philippe E, Bessadok A, Lebrun L, Morvan C, Marais S. Effect of chemical treatments on water sorption and mechanical properties of flax fibres. Bioresource Technol 2009;100(20):4742-4749.

[23] Marais S, Gouanvé F, Bonnesoeur A, Grenet J, Poncin-Epaillard F, Morvan C, Métayer M. Unsaturated polyester composites reinforced with flax fibres: effect of cold plasma and autoclave treatments on mechanical and permeation properties. Compos Part A-Appl S 2005;36:975-986.

[24] Bessadok A, Roudesli S, Marais S, Follain N, Lebrun L. Alfa fibres for unsaturated polyester composites reinforcement: Effects of chemical treatments on mechanical and permeation properties. Compos Part A-Appl S 2009;40:184-195.

[25] Abdelmouleh M, Boufi S, Belgacem MN, Dufresne A. Short natural-fibre reinforced polyethylene and natural rubber composites: Effect of silane coupling agents and fibres loading. Compos Sci Technol 2007;67:1627-1639.

[26] Delahaye N, Marais S. Characterization of unsaturated polyester resin cured with styrene. J Appl Polym Sci 1998;67:695-703.

[27] Crank J, Park GS. In Diffusion in polymers. Academic Press, London and New York: 1968.

[28] Frisch HL. The time lag in diffusion. J Phys Chem 1958;62(4):401-404

[29] Van Krevelen DW. Properties of polymers. Their estimation and correlation with chemical structure. Elsevier Scientific publishing compagny, Amstersdam and Oxford and New York: 1976.

[30] Dhakal HN, Zhang ZY, Richardson MOW. Effect of water absorption on the mechanical properties of hemp fibre reinforced unsaturated polyester composites. Compos Sci Technol 2007;67:1674-1683. 
[31] Zhao FM, Okabe T, Takeda N. The estimation of statistical fibre strength by fragmentation tests of single-fibre composites. Compos Sci Technol 2000;60:1965-1974.

[32] Hodzic A, Kalyanasundaram S, Kim JK, Lowe AE, Stachurski ZH. Application of nano-indentation, nano-scratch and single fibre tests in investigation of interphases in composite materials. Micron 2001;32:765-775.

[33] Zidi M, Carpentier L, Chateauminois A, Kapsa P, Sidoroff F. Development of a micro-indentation model simulating different mechanical responses of the fibre/matrix interface. Compos Sci Technol 2001;61:369-375.

[34] Baley C, Busnel F, Grohens Y, Sire O. Influence of chemical treatments on surface properties and adhesion of flax fibre-polyester resin. Compos Part A-Appl S 2006;37:1626-1637. 


\section{Figure captions}

Figure 1: Composite preparations with a steel home-made mold.

Figure 2: Pictures of a) Unsaturated polyester matrix and b) Flax fibres composite.

Figure 3a: Liquid water sorption kinetics of UPR/flax fibres composites correlated to water sorption isotherms of fibres.

Figure 3b: Normalised mass gain of water liquid sorption in UPR and flax fibres based composites.

Figure 4a: Water permeation through UPR and flax fibres based composites.

Figure 4b: Normalised water permeation flux curves through UPR and flax fibres based composites.

Figure 5: A schematic representation of water permeation phenomenon into UPR/flax fibres composites.

\section{Table Captions}

Table 1: Coefficients and characteristic times of water permeability of UPR/flax fibres based composites. 
Table 1: Coefficients and characteristic times of water permeability of UPR/flax fibres based composites.

\begin{tabular}{|c|c|c|c|c|}
\hline & $\begin{array}{c}\text { Permeability } \\
\text { (Barrer) }\end{array}$ & \multicolumn{3}{|c|}{$\begin{array}{l}\text { Characteristic times } \\
\qquad\left(10^{8} \text { s.cm }^{-2}\right)\end{array}$} \\
\hline & $\boldsymbol{P}$ & $t_{d} / L^{2}$ & $t_{L} / L^{2}$ & $t_{e} / L^{2}$ \\
\hline UPR & 1190 & 0.02 & 0.12 & 0.38 \\
\hline UPR + Untreated flax fibres ( $31 \%$ ) & 7310 & 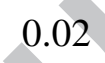 & 0.21 & 0.91 \\
\hline UPR + (S) treated flax fibres $(42 \%)$ & 1810 & 0.86 & 0.99 & 1.10 \\
\hline $\mathrm{UPR}+(\mathrm{Si})$ treated flax fibres $(58 \%)$ & 2290 & 2.67 & 2.95 & 3.25 \\
\hline
\end{tabular}


Alix et al. Study of water behaviour of chemically treated flax fibres based composites: a way to approach the hydric interface

Figure 1: Composite preparation with a steel home-made mold.

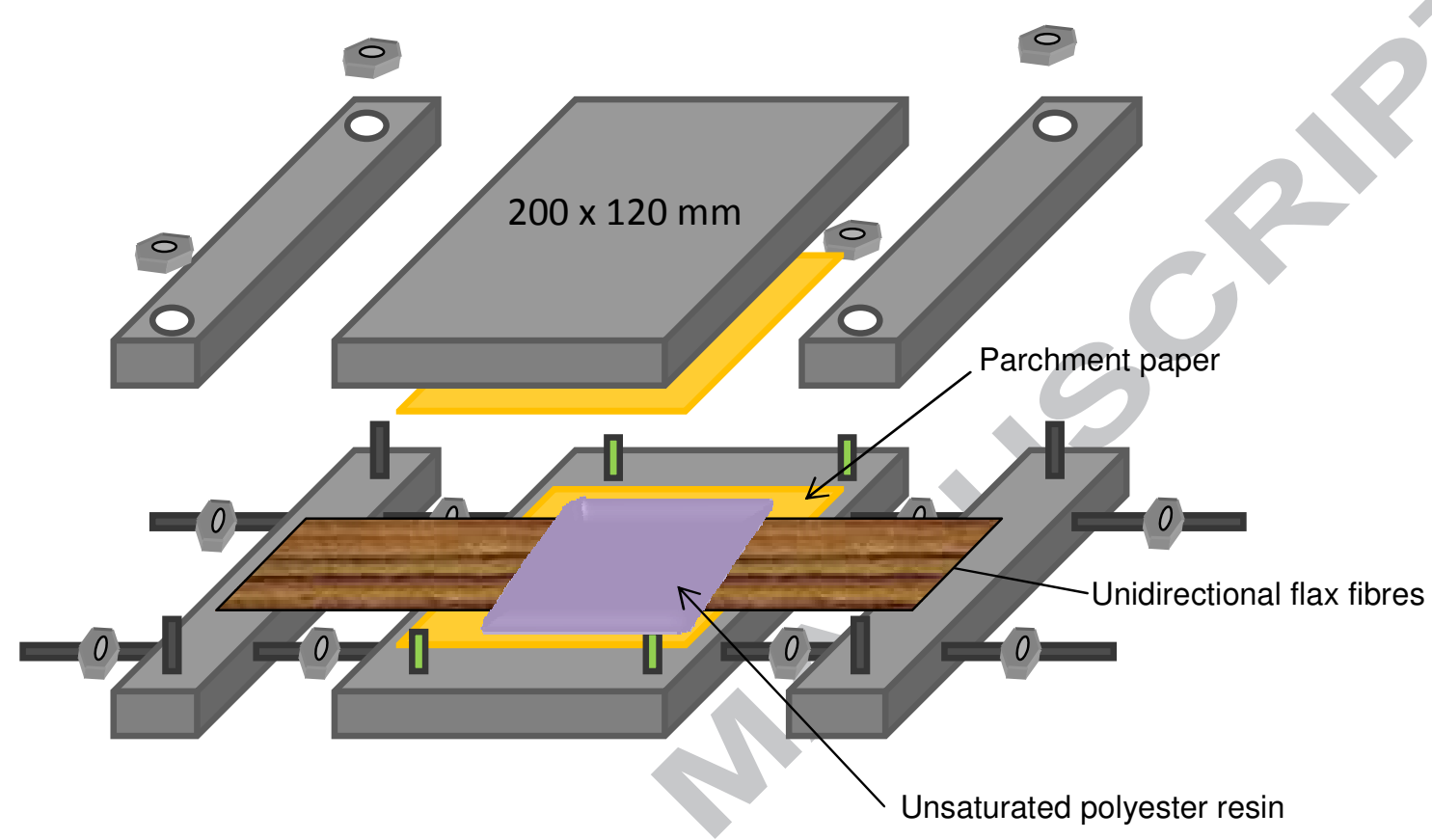


Figure 2: Pictures of a) Unsaturated polyester matrix and b) Flax fibre based composite.

a)

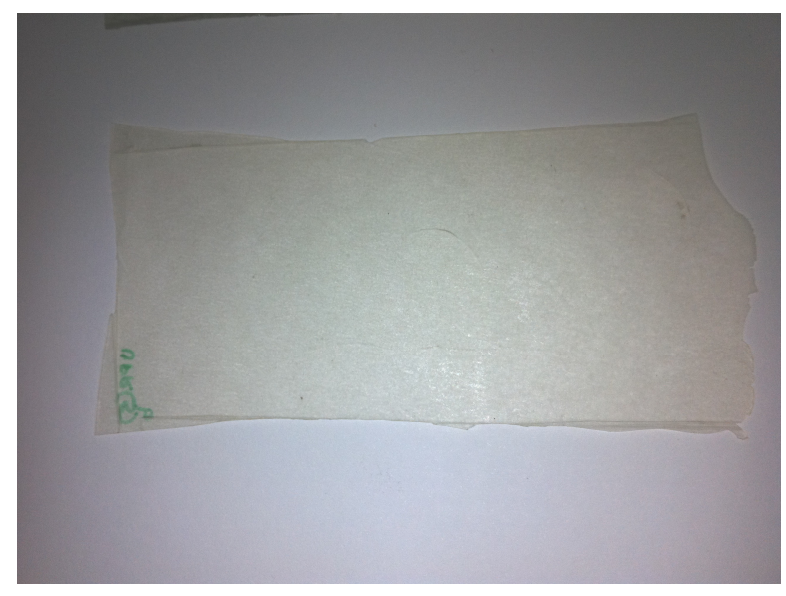

b)

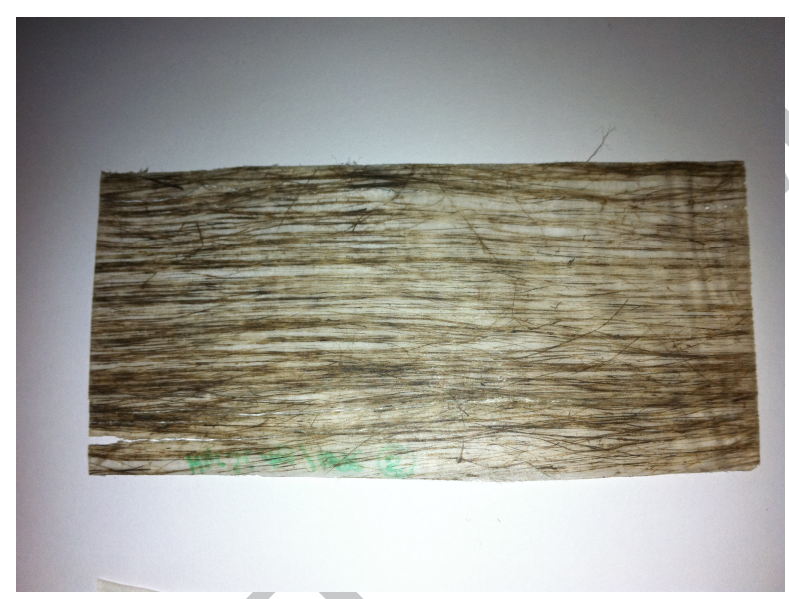


Figure 3a: Liquid water sorption kinetics of UPR/flax fibres composites correlated to water sorption isotherms of fibres.

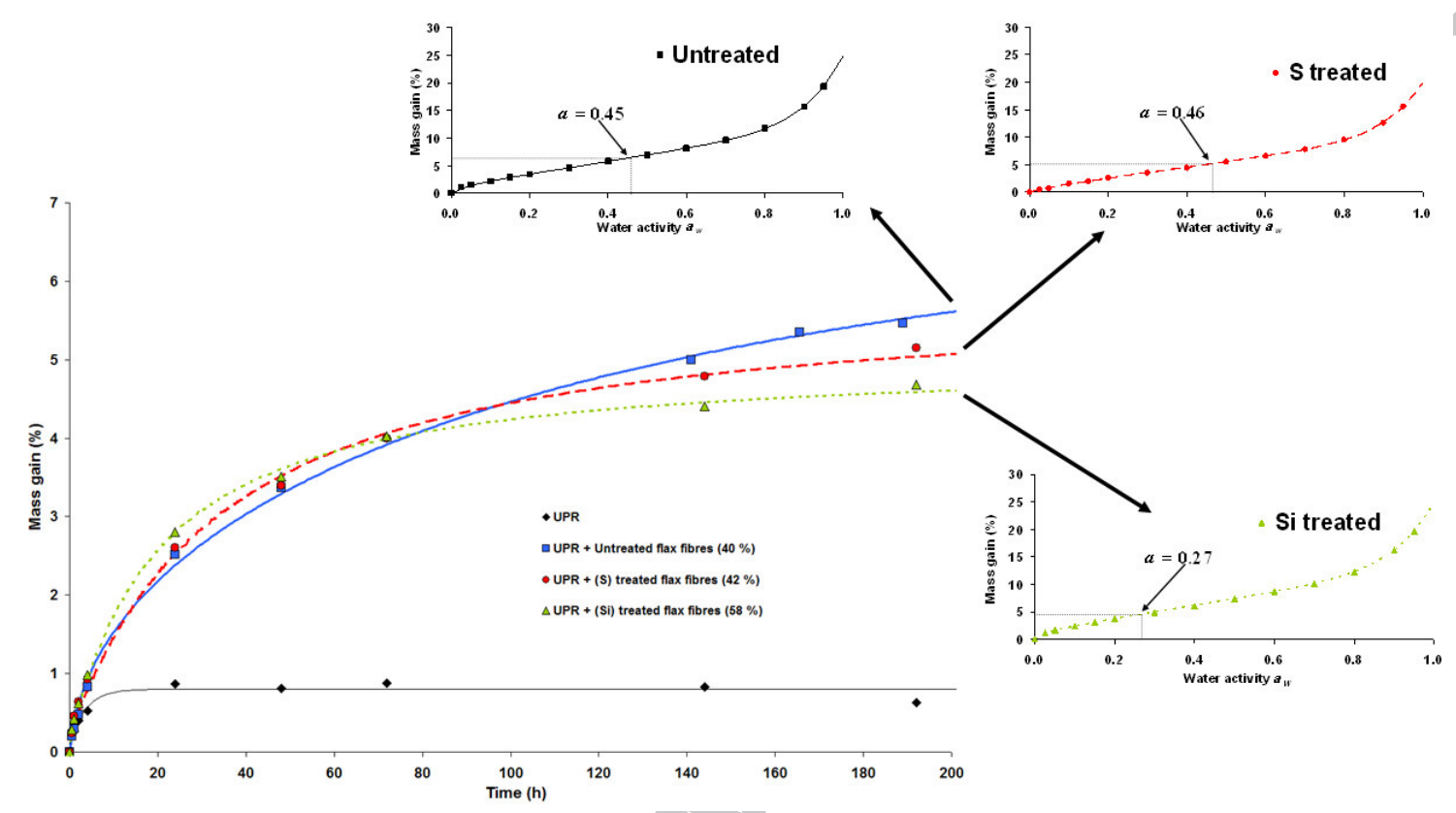


Figure 3b: Normalised mass gain of water liquid sorption in UPR and flax fibres based composites.

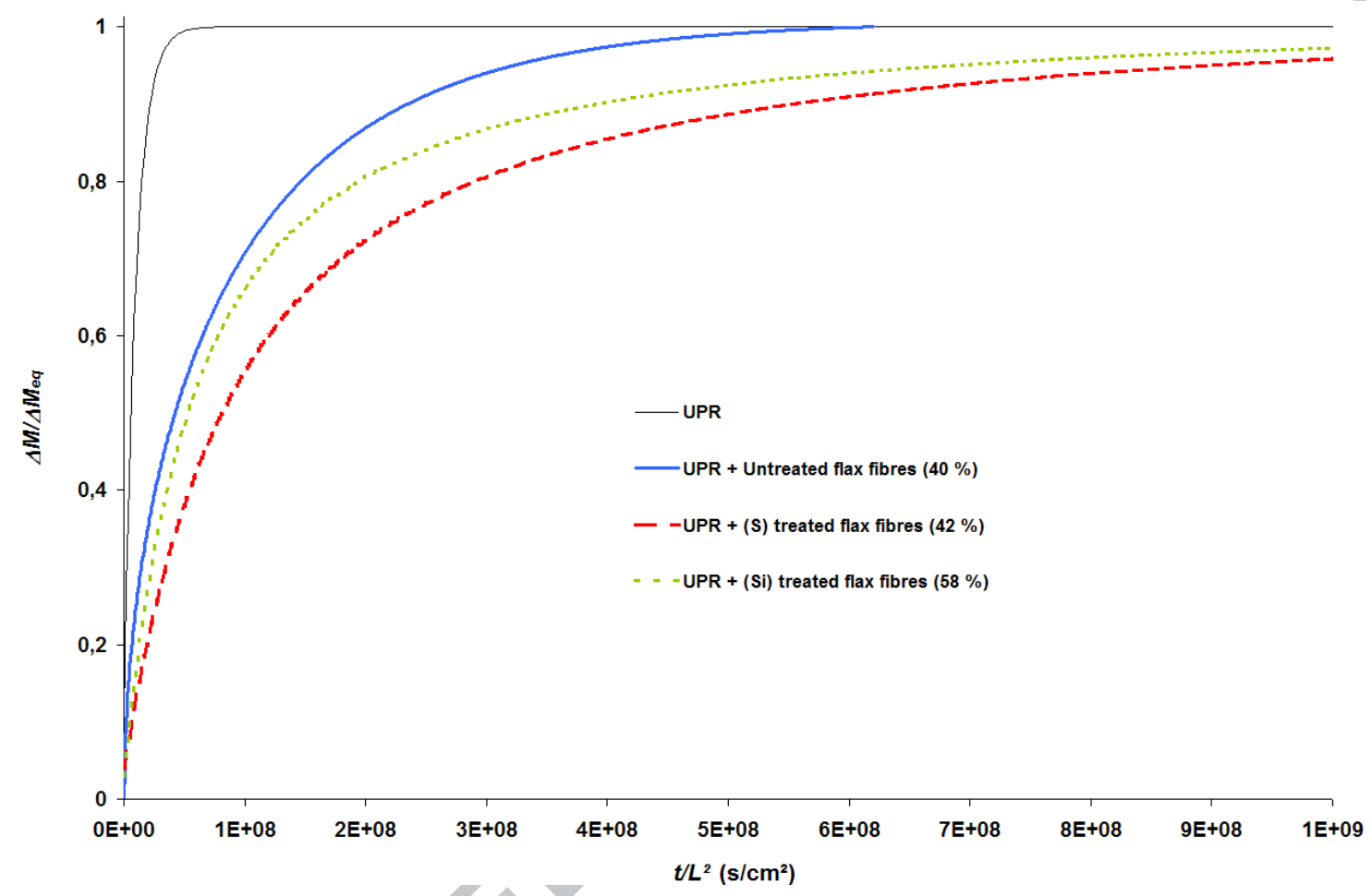


Figure 4a: Water permeation through UPR and flax fibres based composites.

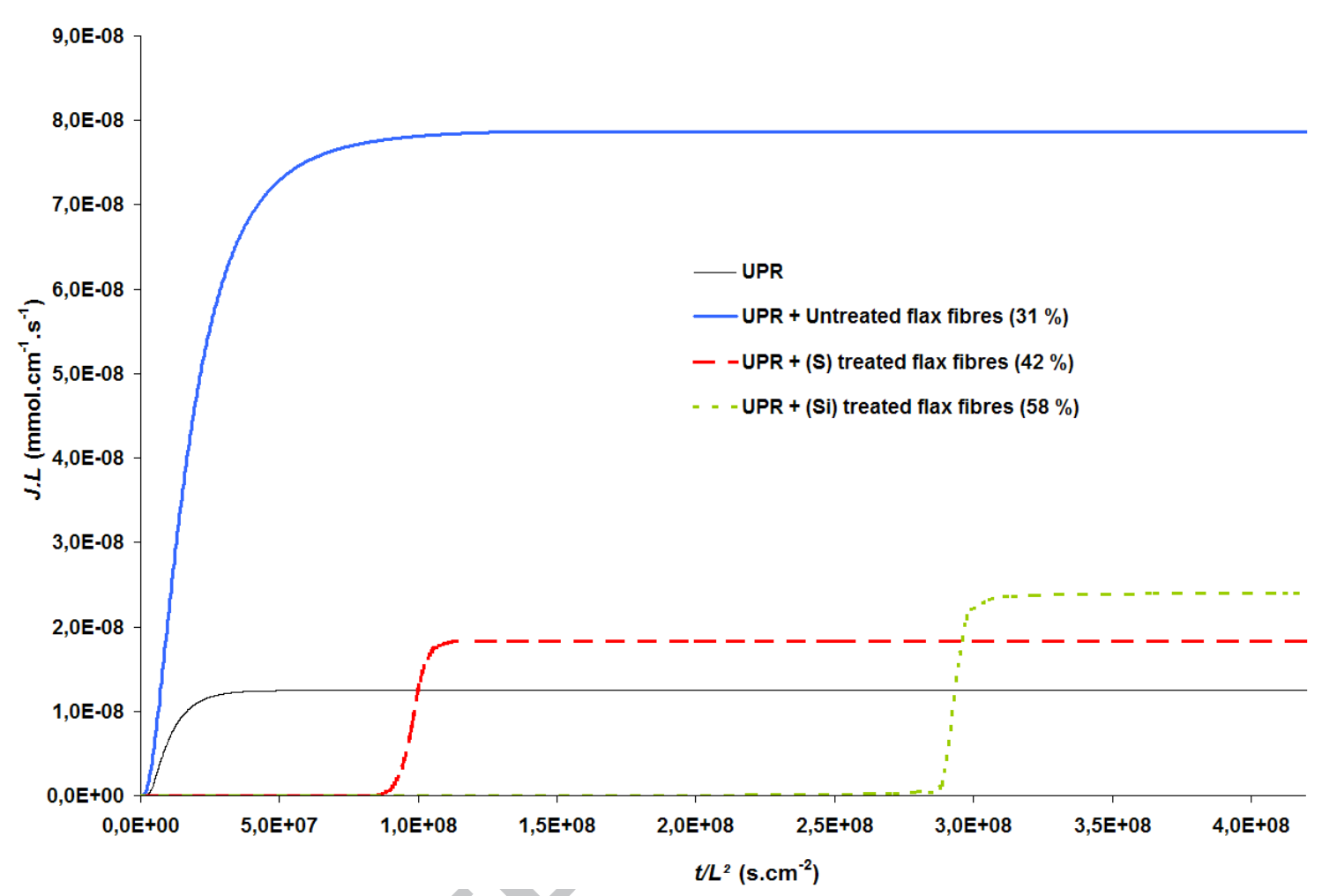


Figure 4b: Normalised water permeation flux curves through UPR and flax fibres based composites.

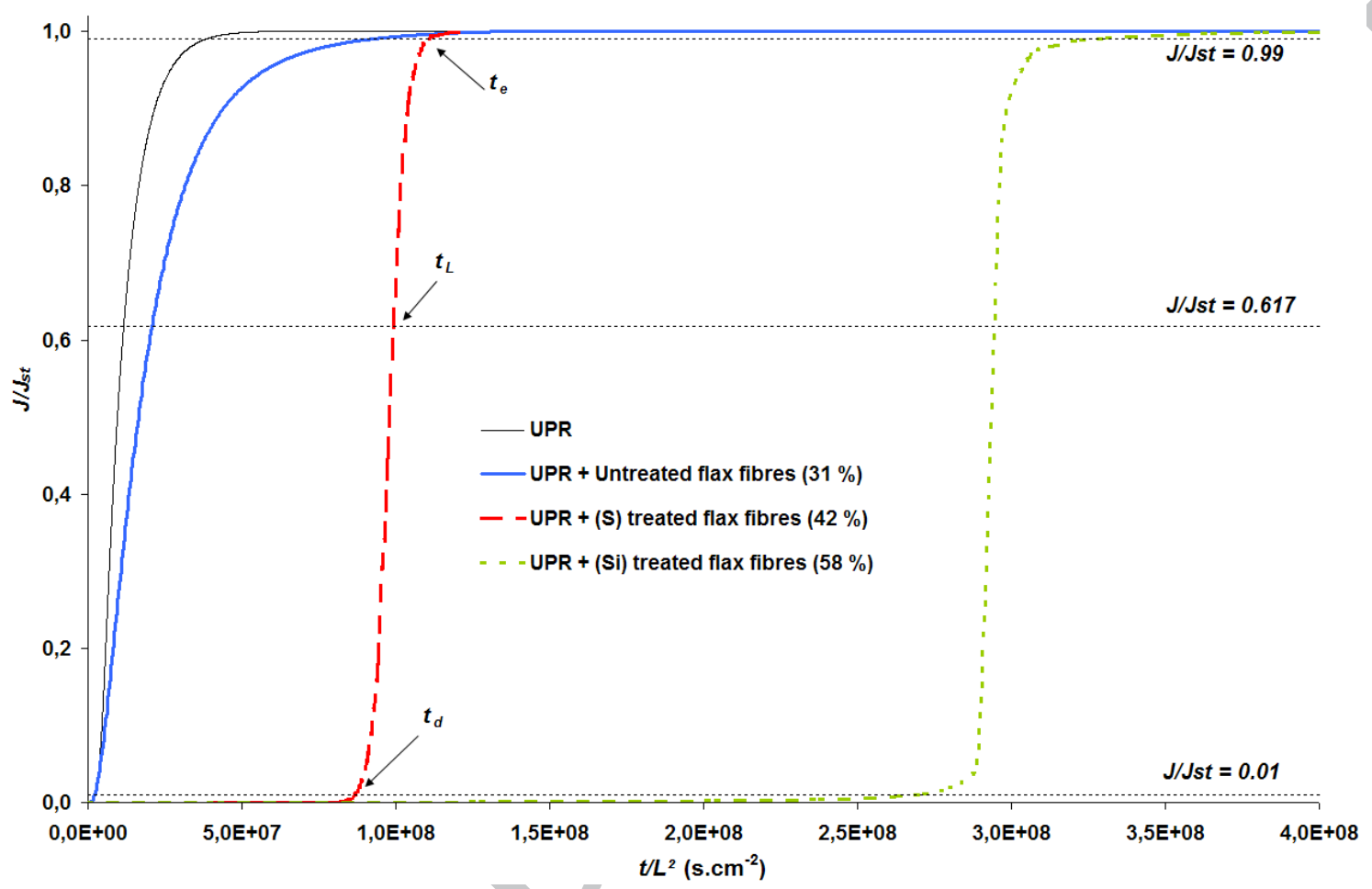


Figure 5: A schematic representation of water permeation phenomenon into UPR/flax fibres composites.

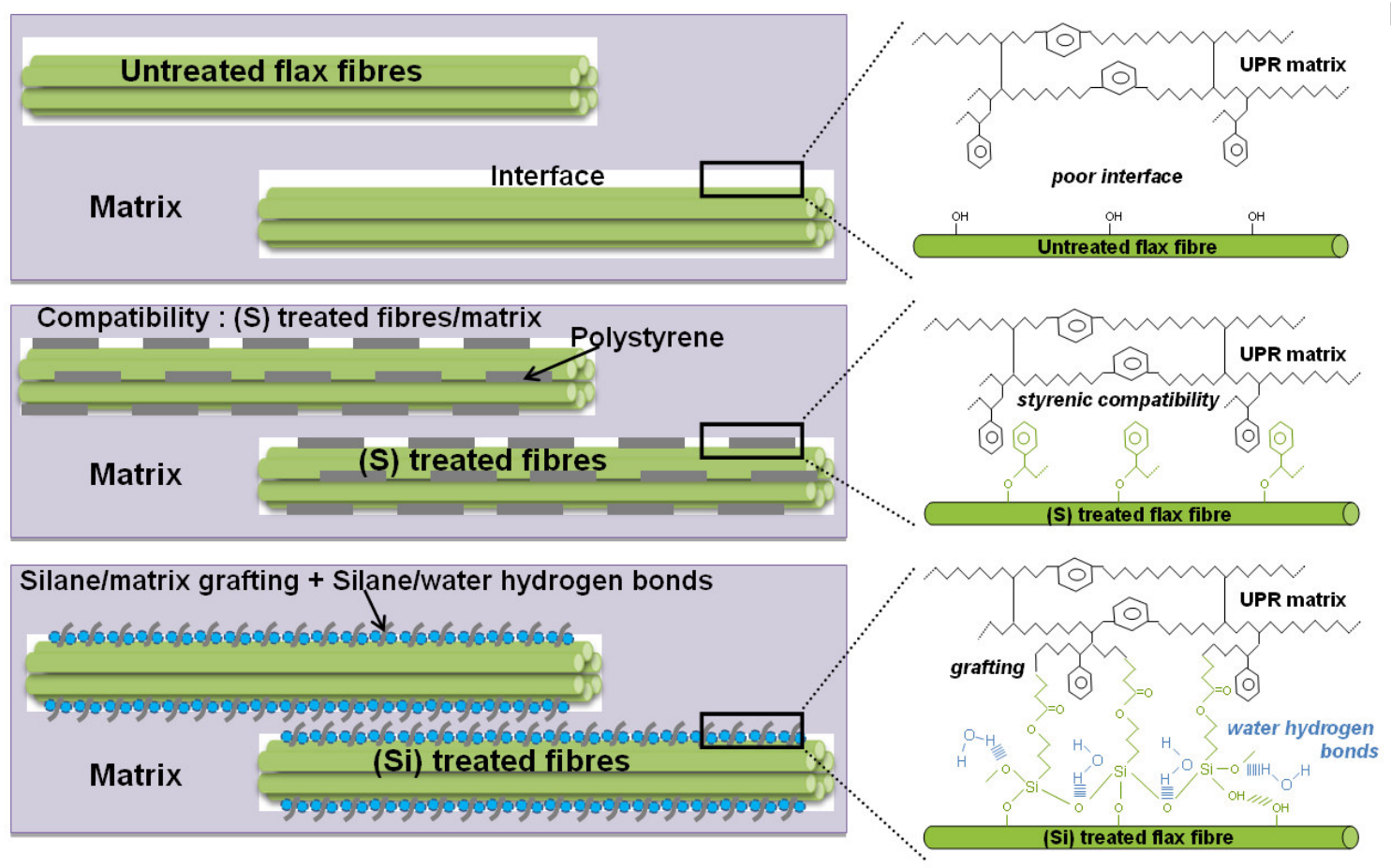

